\title{
HEART CONDITIONED RESPONSE IN SALMO TRUTTA (L.) IN THE FIELD OF INDUCTIVE CURRENT
}

\author{
REAKCJA ODRUCHOWA SERCA U SALMO TRUTTA (L.) \\ W POLU PRAZDU INDUKCYJNEGO
}

From Department of Fish Physiology

Head: Doc. Dr. Rémigiusz Węgrzynowicz

Heart conditioned responses in Salmotrutta (L.) in the field of inductive current were investigated by means of the cardiographic method. High excitability grade was proved. Heart responses appeared after the use of subthreshold stimuli for smooth muscles.

The influence of inductive current on the reaction of fish heart in situ was made a subject of few investigations ( $M \circ \mathrm{h} \mathrm{r}, 1960$; $\mathrm{B}$ o d r o va, K r a$\mathrm{j} \mathrm{u} \mathrm{c} \mathrm{h} \mathrm{i} \mathrm{n,} \mathrm{1948).} \mathrm{Investigations} \mathrm{within} \mathrm{this} \mathrm{range} \mathrm{were,} \mathrm{for} \mathrm{the} \mathrm{most} \mathrm{part,}$ carried out on isolated hearts or by means of vivisection.

By the method of cardiography in chronic experiments there were carried out investigations upon conditioned heart responses of fishes under aquarium conditions in the field of inductive current activity.

\section{EXPERIMENT}

Investigations were carried out on Salmo trutta (L.) of the length from $54 \mathrm{~cm}$ to 66 and weight from 1,5 to $3,5 \mathrm{~kg}$ taken from the river shortly before the experiment. After the operation facilitating the recording of heart work (W e g r z y n o w i c z, Z b a n y s z ek, 1969), the fishwas transferred to the darkened aquarium filled with river water the temperature of which was unchanged, additionally aerated. The fish was left there for adaption. Stopping of increased locomotory movements and the appearance of regular heart action, with allowance for slight variability being within the range of physiological rest, had been accepted as the end of the adaption period.

An accumulator of the initial voltage $2 \mathrm{~V}$ and amperage 3,5 A supplying Dubois Reymond's induction coil was the source of current. Electrodes were 
immersed in water, each of them placed on the opposite wall of the aquarium $(150 \times 80 \times 60 \mathrm{~cm})$.

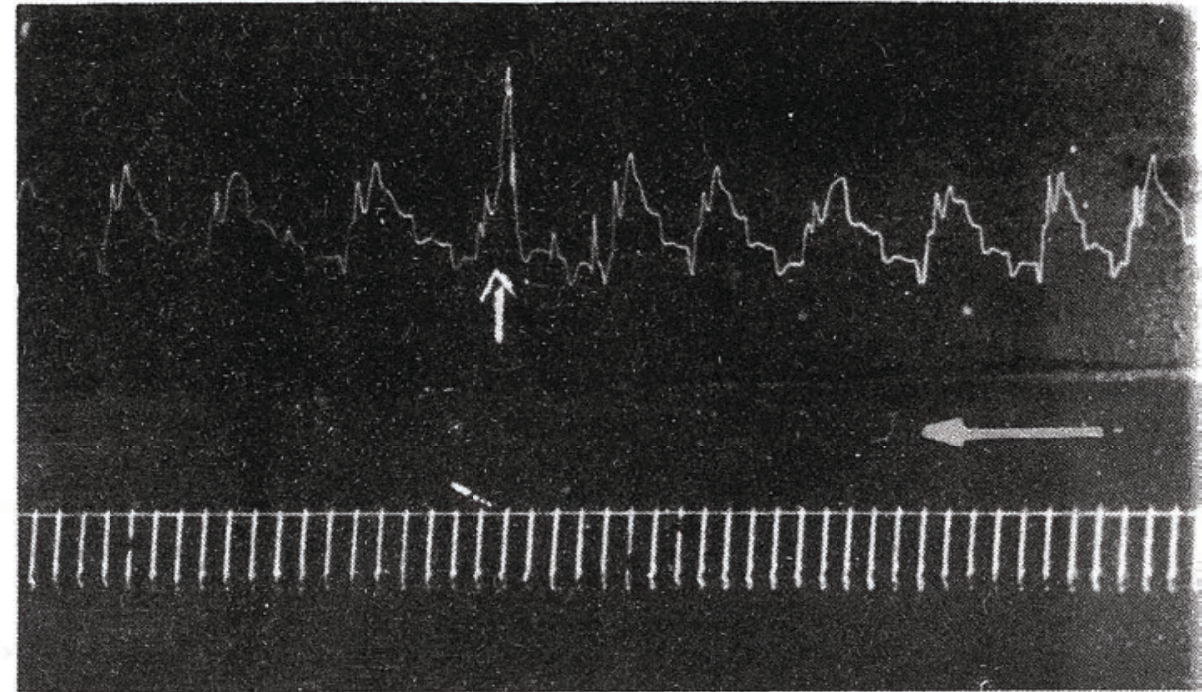

Fig.1. Cardiogram of Salmo trutta, extrasystole as a reaction on single stimulus, bottom: time in sec

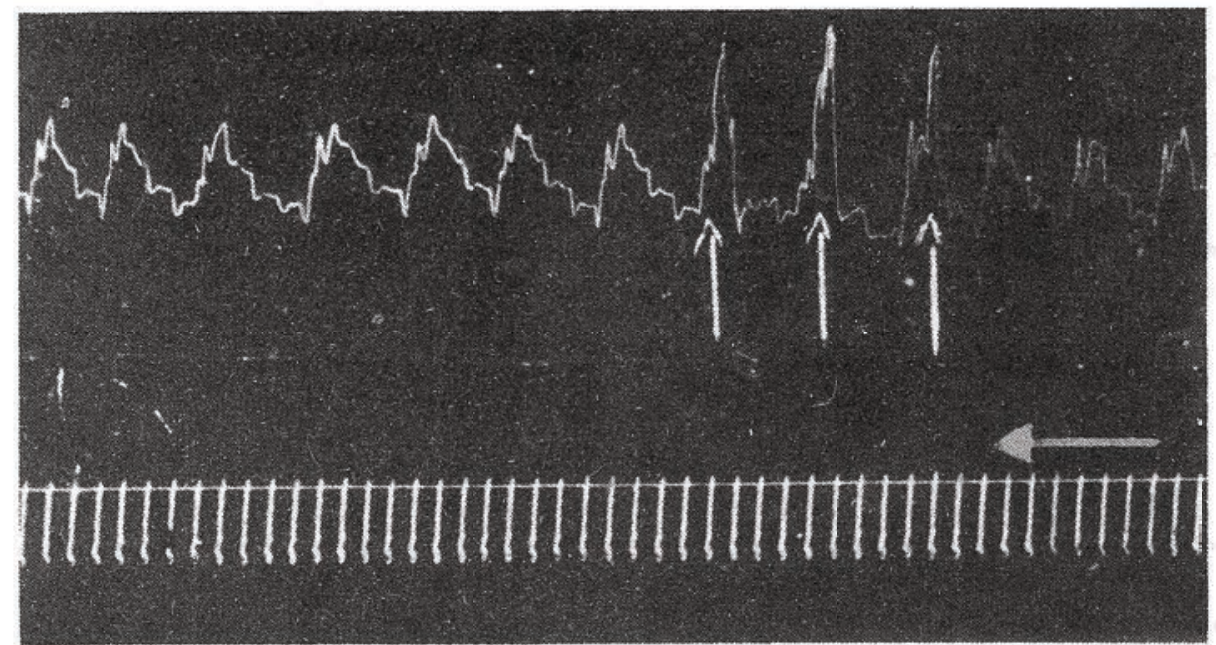

Fig.2. Cardiogram of Salmo trutta, extrasystole as a reaction on single stimulus to the rhythme of successive heart systoles, bottom: time in sec

In the first part of experiments there was defined the threshold of response to single stimuli lasting $1 \mathrm{sec}$. The experiments showed that the response threshold to single stimuli (1 sec. Fig.1) under the above-aquarium described conditions, was within 8-12 cm of the induction coil gap. 
In the second part of investigations there were recorded changes in the heart function influenced by single stimuli repeated to the rhythm of successive heart systoles. Fig. 2 illustrates the obtained results.

\section{DISCUSSION}

The investigations show that there exist heart reactions in fishes examined in the field of inductive current impulses. Heart reaction was marked by extrasystole on a cardiographic curve. The lack compensatory intervalafter extrasystole should be explained by the influence upon sinus which is the source of physiological stimuli. Impulses applied during the experiments did not cause any reactions either within accelerated locomotory movements or in muscle reactions (so called tension) hithertostated, to be the first degree of reactions to electric stimuli. Thus, stimuli applied were subliminal for these reactions. The results show that single impulses (within the range used in experiments) applied even during successive heart systoles following one after another did not change heart action evidently, except for extrasystoles resulting from the activity of the stimulus itself.

As it follows from the carried out experiments, the circulatory system of fish shows a high degree of excitability and it may be the base of investigations upon reactions to electric stimuli of little strength not yet bringing about muscle reactions.

\section{REFERENCES}

M o h r H., 1960: Zum Verhalten der Fische gegenüber Fanggeräten Protokolle zur Fischereitechnik. VI, 29. Hamburg.

Bodrova Il.. Kra juchin B.W., 1948: Do spostreżeń nad vplivom električnogo strumu na morskich ryb. Zbornik posvjaščenyj pamiati A.W. Leontoviča. Kijev.

We grzynowicz R., Z b a n y s z e k R., 1969: Metoda kardiografii u ryb w warunkach akwaryjnych. Acta Ichthyologica et Piscatoria. WSR. Szczecin.

\section{REAKCJA ODRUCHOWA SERCA U SALMO TRUTTA (L.) W POLU PRĄDU INDUKCYJNEGO}

$$
\text { Streszczenie }
$$

W oparciu o metodę kardiografii przeprowadzono badania reakcji serca u troci Salmo trutta (L.) pod wpływem działania prądu indukcyjnego w wa- 
runkach akwaryjnych. Impulsy pojedyncze (2 V i 3,5 A) trwające 1 sek. wywoływały extrasystole, jak również reakcję odruchową mięśni szkieletowych.

\author{
РЕФЛЕКТОРНАЯ РЕАКЦИЯ СЕРДLА У SALMO TRUTTA I. \\ В ПОЛЕ ИНДУКЦИОННОГО ТОКА
}

$$
\text { P e } 3 \text { io } \mathrm{Me}
$$

Исходя из метода кардиографиии проиводились испытания по реакции сердца у лосось-тюйменей (Salmo trutta L.) под влиянием воздейст:вия индукционного тока в акварюмных условиях. Единичные импульсы (2 V и 3,5 A) продолжительностью в 1 сек. вызывали экстрасистоли, а также рефилекторную реакцию шкелетовых мышц.

\title{
Address:
}

Doc.dr Remigiusz Węgrzynowicz

Katedra Fizjologii Ryb WSR

Szczecin, ul.Kazimierza Królewicza 4

Polska - Poland

Received 2O.VII. 1968 